\title{
NO Sensitizes Rat Hepatocytes to Proliferation by Modifying S-Adenosylmethionine Levels
}

\author{
ELENA R. GARCíA-TREVIJANO, MARÍA L. MARTÍNEZ-CHANTAR, M. UJUE LATASA, \\ JOSÉ M. MATO, and MATÍAS A. AVILA \\ División de Hepatología y Terapia Génica, Departamento de Medicina Interna, Facultad de Medicina, Universidad de Navarra, \\ Pamplona, Spain
}

Background \& Aims: Liver regeneration is a fundamental response of this organ to injury. Hepatocyte proliferation is triggered by growth factors, such as hepatocyte growth factor. However, hepatocytes need to be primed to react to mitogenic signals. It is known that nitrous oxide (NO), generated after partial hepatectomy, plays an important role in hepatocyte growth. Nevertheless, the molecular mechanisms behind this priming event are not completely known. S-adenosylmethionine (AdoMet) synthesis by methionine adenosyltransferase is the first step in methionine metabolism, and NO regulates hepatocyte S-adenosylmethionine levels through specific inhibition of this enzyme. We have studled the modulation of hepatocyte growth factor-induced proliferation by NO through the regulation of S-adenosylmethionine levels. Methods: Studies were conducted in cultured rat hepatocytes isolated by collagenase perfusion, which triggers NO synthesis. Results: The mitogenic response to hepatocyte growth factor was blunted when inducible NO synthase was inhibited; this process was overcome by the addition of an NO donor. This effect was dependent on methionine concentration in culture medium and intracellular S-adenosylmethionine levels. Accordingly, we found that S-adenosylmethionine inhibits hepatocyte growth factor-induced cyclin D1 and D2 expression, activator protein 1 induction, and hepatocyte proliferation. Conclusions: Together our findings indicate that NO may switch hepatocytes into a hepatocyte growth factor-responsive state through the downregulation of S-adenosylmethionine levels.

$\mathrm{L}$ iver regeneration after tissue damage is a fundamen$L_{\text {tal feature of this organ that likely evolved as a }}$ defense mechanism against food-borne toxic insults. ${ }^{1,2}$ Experimentally, this response can be induced by the surgical removal of approximately $70 \%$ of the liver tissue (partial hepatectomy $[\mathrm{PH}]),{ }^{3}$ which triggers the proliferation of the remaining parenchymal cells that divide once or twice, quickly restoring the original liver mass. ${ }^{1,2}$ Serial hepatocyte transplantation experiments have evidenced the enormous proliferative potential of this cell type, which exceeds that of hematopoietic precursor cells. ${ }^{4}$ Much effort has been dedicated to the elucidation of the mechanisms that trigger hepatocyte proliferation after $\mathrm{PH}$. The role of growth factors, such as hepatocyte growth factor (HGF), in the mitogenic response of hepatocytes after PH has been clearly established. ${ }^{1,2}$ However, quiescent hepatocytes in normal liver are not ready to respond to proliferative stimuli, and need to be primed to respond to the mitogenic signals conveyed by HGF and other growth factors. ${ }^{1,2}$ Inducible nitric oxide synthase (iNOS) expression and NO production are induced early after $\mathrm{PH} .{ }^{5}$ This response must be important because inhibition of NO production after $\mathrm{PH}$ impairs hepatocyte DNA synthesis, ${ }^{5}$ and iNOS knockout mice display abnormal liver regeneration and enhanced hepatocellular apoptosis. ${ }^{6}$ The mechanisms behind these effects of NO in regenerating liver cells are not completely known.

One of the best characterized targets for NO in the hepatocyte is methionine adenosyltransferase (MAT), the enzyme responsible for the conversion of methionine into S-adenosylmethionine (AdoMet). ${ }^{7}$ Two genes encode for MAT: MAT1A and MAT2A;MAT1A is the gene predominantly expressed in the adult liver, whereas $M A T 2 A$ expression is widely distributed. ${ }^{8}$ We have previously shown that the activity of MAT I/III, the product of MAT1A, is specifically inhibited in vitro and in vivo by NO through S-nitrosylation of cysteine 121, a position occupied by glycine in MAT II, the product of $M A T 2 A$, leading to reduced hepatocyte AdoMet contents. ${ }^{9-12}$ Cellular levels of AdoMet seem to be related to the differentiation status of the hepatocyte. In this re-

\footnotetext{
Abbreviations used in this paper: AdoMet, S-adenosylmethionine; AP1, activating protein 1; ERK, extracellular signal-regulated kinase; HGF, hepatocyte growth factor; IKBa, inhibitor kappa B alpha; INOS, inducible nitric oxide synthase; L-NAME, $N^{G}$-monomethyl-L-arginine methyl ester; MAT, methionine adenosyltransferase; NF-кB, nuclear factor $\mathbf{\kappa}$; $\mathrm{PH}$, partial hepatectomy; SNAP, S-nitroso- $\mathrm{N}$-acetylpenicillamine; TGF, transforming growth factor.

(C) 2002 by the American Gastroenterological Association 0016-5085/02/\$35.00 doi:10.1053/gast.2002.33020
} 
gard, quiescent and proliferating hepatocytes display different AdoMet contents, being lower in the growing cells. This has been observed in rat liver after $\mathrm{PH}$, where AdoMet levels are dramatically reduced shortly after the intervention, coinciding with the onset of DNA synthesis and the induction of early-response genes. ${ }^{13}$ When this decrease in AdoMet after $\mathrm{PH}$ was prevented by the intraperitoneal administration of AdoMet, hepatocyte DNA synthesis was inhibited. ${ }^{14,15}$ Additionally, exogenous addition of AdoMet to cultured rat hepatocytes inhibits HGF-induced gene expression and the growth of hepatoma cells in culture. ${ }^{16,17}$ This notion has received further support when MAT1A knockout mice became available. In these animals, hepatic AdoMet levels are reduced by $75 \%$ of wild-type levels, and the expression of growth- and dedifferentiation-related genes (such as the proliferating cell nuclear antigen and $\alpha$-fetoprotein) is markedly induced. ${ }^{18}$ Accordingly, these mice show enhanced liver growth. ${ }^{18}$

Taken together, these observations have led us now to postulate that changes in hepatocyte AdoMet levels, through the inhibitory effect of NO on MAT I/III activity, could contribute to switch the hepatocyte into an HGF-responsive state. In the present report, we have evaluated this hypothesis in cultured rat hepatocytes, taking advantage of the induction of iNOS expression that occurs during collagenase perfusion of rodent liver. ${ }^{19,20}$

\section{Materials and Methods}

AdoMet, sulfate-p-toluenesulfonate salt, was from Europharma (Madrid, Spain) (produced by Knoll, Milan, Italy). $\left[{ }^{3} \mathrm{H}\right]$ Thymidine $(25 \mathrm{Ci} / \mathrm{mmol})$ was from Amersham (Little Chalfont, UK). Human recombinant $\mathrm{HGF}$ and transforming growth factor- $\alpha$ (TGF $\alpha$ ) were from Calbiochem (Darmstadt, Germany). $\quad S$-nitroso- $N$-acetylpenicillamine (SNAP), $\quad N^{G}$ monomethyl-L-arginine methyl ester (L-NAME), and all other chemicals, otherwise stated, were from Sigma (St. Louis, MO). All antibodies and the mutant AP1 oligonucleotide were from Santa Cruz Biotechnology (Santa Cruz, CA), and their references were as follows: cyclin D1 sc-450, cyclin D2 sc-593, phospho ERK 1/2 sc-7383, actin sc-8432, c-Fos sc-52x, c-Jun sc- $45 x$, Fral sc-183x, JunB sc- $46 x$, JunD sc- $74 x$.

\section{Isolation and Culture of Rat Hepatocytes}

Hepatocytes were isolated from male Wistar rats (200 g) by collagenase perfusion (Gibco-BRL, Paisley, UK), as described previously, ${ }^{21}$ Cells were plated onto collagen-coated 6-well dishes (type I collagen from rat tail; Collaborative Biomedical, Bedford, MA), $10^{6}$ cells per well. Cultures were maintained in minimal essential medium supplemented with $5 \%$ fetal bovine serum, nonessential amino acids, $2 \mathrm{mmol} / \mathrm{L}$ glutamine, and antibiotics (all from Gibco-BRL). After a 6-hour incubation, culture medium was removed and cells were refed the same medium without fetal bovine serum, supplemented with $1 \mathrm{mmol} / \mathrm{L}$ L-methionine to preserve MAT1A expression ${ }^{22}$ and, where indicated, $1 \mathrm{mmol} / \mathrm{L}$ L-NAME, and further incubated for 18 hours before the onset of treatments. Cell viability was measured by trypan blue exclusion and by 3-[4,5-dimethylthioazol-2-yl]-2,5-diphenyltetrazolium bromide assay, no significant differences were observed at any time between controls and any of the treatments performed. Animals were treated humanely and according to our institution's guidelines for the use of laboratory animals.

\section{Assay of DNA Synthesis}

For DNA synthesis experiments, hepatocytes were plated at a density of $3 \times 10^{4}$ cells/well in collagen-coated, 96-well, flat-bottomed plates in minimal essential medium supplemented with $5 \%$ fetal bovine serum and cultured as described previously. Before HGF (25 $\mathrm{ng} / \mathrm{mL}$ ) addition, medium was replaced by fresh medium containing increasing concentrations of L-methionine or AdoMet and, where indicated, $200 \mu \mathrm{mol} / \mathrm{L} \mathrm{SNAP}$ and $1 \mathrm{mmol} / \mathrm{L} \mathrm{L}$-NAME. An 8-hour pulse of $\left[{ }^{3} \mathrm{H}\right]$ thymidine $(1 \mu \mathrm{Ci} /$ well $)$ started 20 hours after HGF addition. Cells were harvested and thymidine incorporation was determined in a scintillation counter.

\section{Determination of MAT Activity and AdoMet Content in Cultured Hepatocytes}

Hepatocytes $\left(3 \times 10^{6}\right.$ cells $)$ were lysed and MAT activity was assayed as described previously. ${ }^{23}$ For the determination of AdoMet levels in hepatocytes, cultures were washed with saline and then cells $\left(3 \times 10^{6}\right)$ were lysed and deproteinized as described. ${ }^{10}$ AdoMet contents were determined by reverse-phase high-performance liquid chromatography as described. ${ }^{10}$

\section{Immunoblot Analysis}

For Western blot analysis, hepatocytes were homogenized as previously described. ${ }^{22}$ Equal amounts of protein were subjected to $10 \%$ sodium dodecyl sulfate-polyacrylamide gel electrophoresis. Proteins were transferred to nitrocellulose membranes. iNOS, cyclin D1, cyclin D2, c-Jun, c-Fos, JunB, JunD, Fra1, and phosphoextracellular signal-regulated kinase $1 / 2($ ERK $1 / 2)$ were detected by using the corresponding antibodies and secondary horseradish peroxidase-conjugated antibodies. Blots were developed by enhanced chemoluminescence (Dupont, Boston, MA). Equal loading of the gels was assessed with an antibody specific for actin.

\section{Nuclear Protein Extraction and Electrophoretic Mobility Shift Assays}

Nuclear proteins from control and treated hepatocytes were isolated as described. ${ }^{24}$ An oligonucleotide containing the activating protein 1 (AP1) consensus sequence (5'-TTCCGGGTGACTCATCAAGCG-3') (Promega, Madison, WI), was labeled with $\left(\gamma^{32} \mathrm{P}\right)$ adenosine triphosphate by using $\mathrm{T} 4$ 
polynucleotide kinase (Roche Diagnostics, Barcelona, Spain). Binding reactions were performed as described. ${ }^{24}$ DNA-protein complexes were separated from unbound probe by electrophoresis on a $6 \%$ polyacrylamide gel. Complexes formed were identified by autoradiogtaphy of the dried gels. Specificity and identity of the complexes were assessed by competition and supershift studies.

\section{Statistics}

Data are the means \pm SEM of at least 3 independent experiments. Statistical significance was estimated with the Student $t$ test. A $P$ value of less than 0.05 was considered significant.

\section{Results}

The perfusion of rat liver with collagenase promotes iNOS expression and NO relęase. ${ }^{19,20}$ In agreement with these reports we also observed the induction of iNOS in isolated hepatocytes. Under these experimental conditions we tested the effect of the iNOS inhibitor L-NAME on the mitogenic activity of HGF in cultured rat hepatocytes. As shown in Figure $1 A$, in the presence of L-NAME the proliferative response elicited by HGF was markedly inhibited. Interestingly, this inhibition was overcome when cells were simultaneously treated with the NO donor SNAP. These observations suggested that NO was interacting with some target or targets in the hepatocyte, and that as a consequence the cell would turn into an HGF-responsive state. As previously mentioned, MAT I/III is one of the best characterized targets of NO in the hepatocyte. ${ }^{9-12}$ L-methionine, together with adenosine triphosphate, is the substrate of MAT I/III in the synthesis of AdoMet, and this reaction is inhibited by NO. ${ }^{12}$ When we tested the mitogenic effect of HGF in cells treated with L-NAME in the presence of increasing concentrations of L-methionine, we observed that the inhibitory effect of L-NAME was dependent on the concentration of this amino acid in the culture medium, whereas $\mathrm{D}$-methionine $(1 \mathrm{mmol} / \mathrm{L})$ had no effect (Figure 1B).

Because the first step in methionine metabolism is its conversion into AdoMet, and NO reduces hepatocyte AdoMet content, ${ }^{12}$ we determined the effect of L-NAME on hepatocyte MAT I/III activity and AdoMet levels under the same culture conditions used for the DNA synthesis experiments. We found that inhibition of NO synthesis by L-NAME (24-hour treatment) resulted in increased MAT I/III activity (from 109.3 \pm 9.4 to $161.2 \pm 6.3 \mathrm{pmol} \cdot \mathrm{min}^{-1} \cdot \mathrm{mg}^{-1}$ of protein, $P<0.01$ ) and AdoMet levels (from $83.0 \pm 2.0$ to $103.4 \pm 0.1$ $\mathrm{pmol} / \mathrm{mg}$ of protein, $P<0.05$ ). We subsequently analyzed the effect of AdoMet on the mitogenic action of
A

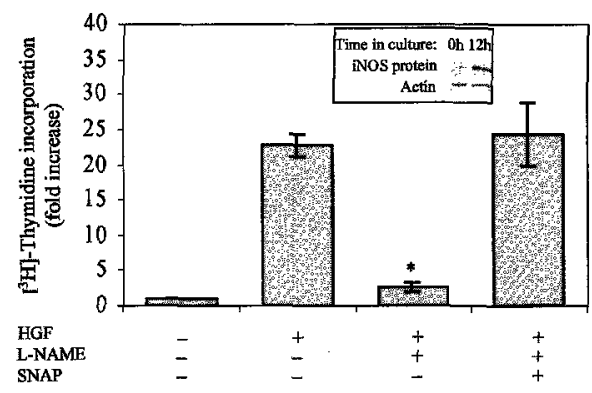

B

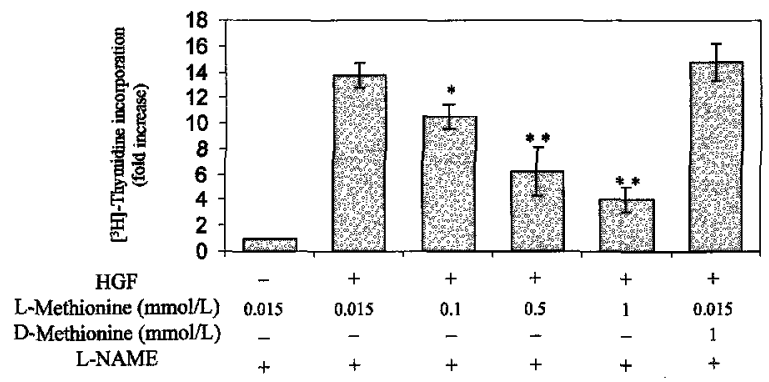

Figure 1. $(A)$ HGF-induced DNA synthesis in isolated rat hepatocytes depends on iNOS activity. iNOS is induced in hepatocytes isolated by collagenase perfusion of rat liver (inset shows Western blot). DNA synthesis was measured as $\left[{ }^{3} \mathrm{H}\right]$ thymidine incorporation in hepatocytes cultured in $1 \mathrm{mmol} / \mathrm{L}$ L-methionine and treated with HGF (25 $\mathrm{ng} / \mathrm{mL}$ for 28 hours), in the presence or absence of L-NAME (1 $\mathrm{mmol} / \mathrm{L})$. The NO donor SNAP $(200 \mu \mathrm{mol} / \mathrm{L})$ reversed the inhibitory effect of L-NAME on hepatocyte proliferation. $* P<0.01$ with respect to cells treated with HGF in the absence of L-NAME and cells treated with HGF in the presence of L-NAME plus SNAP. $(B)$ In the presence of the iNOS inhibitor L-NAME (1 mmol/L), HGF-induced DNA synthesis in cultured rat hepatocytes, measured as $\left[{ }^{3} \mathrm{H}\right]$ thymidine incorporation, is dose-dependently inhibited by the concentration of L-methionine (but not D-methionine) in culture medium. $* P<0.05, * * P<0.01$ with respect to cells treated with $\mathrm{HGF}$ and $0.015 \mathrm{mmol} / \mathrm{L} \mathrm{L}$-methionine.

HGF in cultured rat hepatocytes and found that AdoMet inhibited HGF-induced cell proliferation in a dose-dependent fashion (Figure 2A, left panel). Additionally, the permissive effect of SNAP on HGF-induced DNA synthesis that was observed in the presence of L-NAME was counteracted by the addition of AdoMet $(4 \mathrm{mmol} / \mathrm{L})$ (Figure 2A, right panel). The inhibitory effect of AdoMet ( $4 \mathrm{mmol} / \mathrm{L}$ ) on HGF-induced DNA synthesis could be observed at different time points, as shown in Figure $2 B$.

The inhibitory effect of L-NAME $(1 \mathrm{mmol} / \mathrm{L})$ on hepatocyte proliferation was extended to other hepatocyte mitogens such as TGF $\alpha$. Figure $3 A$ shows how, in the presence of $1 \mathrm{mmol} / \mathrm{L}$ L-methionine, TGF $\alpha$-induced DNA synthesis was blunted when L-NAME was present in the incubation medium. Similarly to what was observed for HGF, AdoMet treatment also inhibited the proliferative effect of TGF $\alpha$ on cultured hepatocytes (Figure 3B). 
A

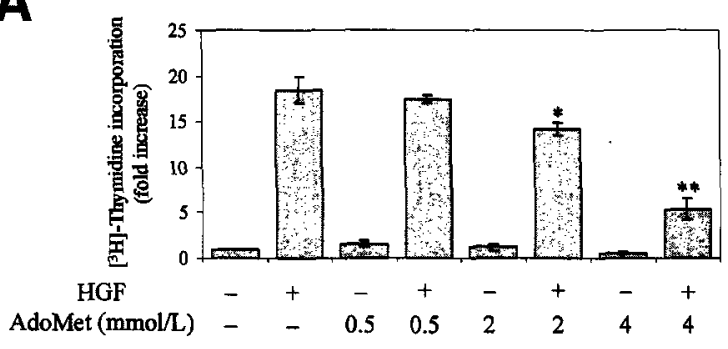

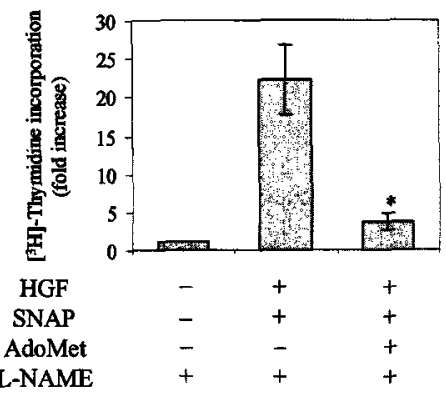

B

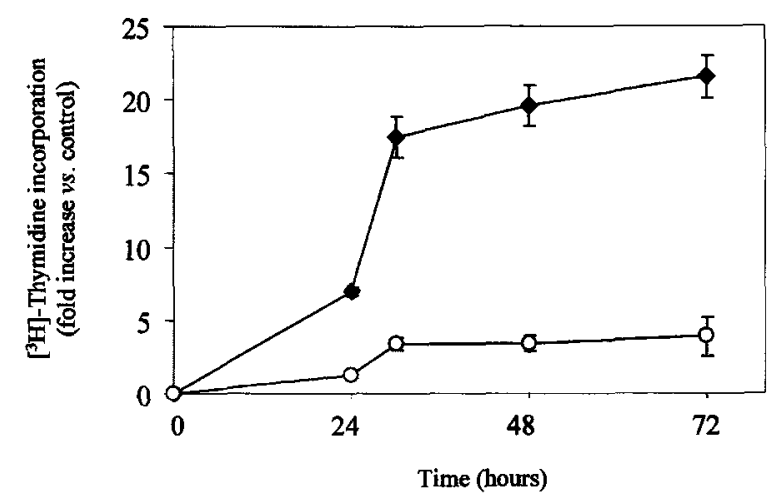

Figure 2. (A) Left panel: Dosedependent inhibition by AdoMet treatment of HGF-induced DNA synthesis in rat hepatocytes. $* P<0.05, * * P$ $<0.01$ with respect to cells treated with HGF alone. Right panel: In the presence of AdoMet $(4 \mathrm{mmol} / \mathrm{L})$ the addition of SNAP $(200 \mu \mathrm{mol} / \mathrm{L})$ does not overcome the inhibitory effect of L-NAME (1 $\mathrm{mmol} / \mathrm{L}$ ) on HGF-induced DNA synthesis. (B) Effect of AdoMet (4 mmol/L) on HGF-induced DNA synthesis in rat hepatocytes measured at different time points. $\bullet$ HGF alone; $O$, HGF plus AdoMet.
Growth factor (HGF, epidermal growth factor) treatment of cultured hepatocytes results in the induction of type D cyclin gene expression, ${ }^{25,26}$ of which cyclin D1 has been recognized as the most reliable marker for cell cycle ( $\mathrm{G} 1$ phase) progression in hepatocytes. ${ }^{2}$ Now we observe that, in the presence of L-NAME, the accumulation of cyclin D1 protein in response to HGF (25 $\mathrm{ng} / \mathrm{mL}, 27$ hours) was dependent on the concentration of L-methionine in the culture medium (Figure $4 A$ ), and was completely abolished by the simultaneous addition of the NO donor SNAP $(200 \mu \mathrm{mol} / \mathrm{L})$.

This observation suggested that the effect of L-methionine was dependent on its conversion into AdoMet. Accordingly, in the presence of AdoMet $(4 \mathrm{mmol} / \mathrm{L})$, induction of cyclin D1 and D2 expression by HGF (25 $\mathrm{ng} / \mathrm{mL}, 27$-hour treatment) was substantially reduced (Figure $4 B$ ). However, activation of ERK $1 / 2$ phosphorylation induced by $\mathrm{HGF}$, which occurs upstream of cyclin induction, was not affected by AdoMet treatment (Figure 4B).

Activation of AP1 transcription factor has been shown to occur in the liver of rats after $\mathrm{PH},{ }^{2}$ and it is known that HGF induces AP1 activation in cultured hepatocytes. ${ }^{24,27}$ Given the major role played by this transcription factor in the regulation of liver growth during regeneration, ${ }^{28}$ we tested whether AdoMet could interfere with its induction by HGF. For this purpose cultured hepatocytes were treated with HGF $(25 \mathrm{ng} / \mathrm{mL}, 24$ hours) in the presence or absence of AdoMet $(4 \mathrm{mmol} / \mathrm{L})$, and AP1 binding activity in nuclear protein extracts was examined by electrophoretic mobility shift assays.

A

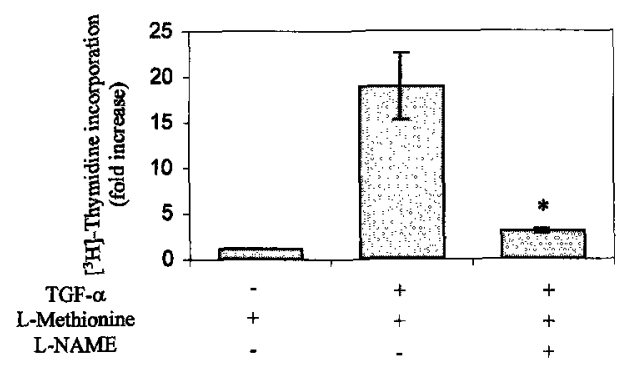

B

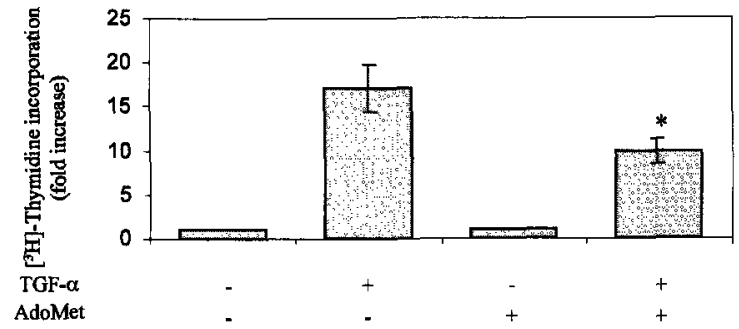

Figure 3. (A) Induction of DNA synthesis by TGF $\alpha(10 \mathrm{ng} / \mathrm{mL}$ for 28 hours) is inhibited by $1 \mathrm{mmol} / \mathrm{L}$ L-methionine when iNOS was inhibited by L-NAME $(1 \mathrm{mmol} / \mathrm{L}) . * P<0.01$ with respect to cells treated with TGF $\alpha$ in the absence of L-NAME. (B) AdoMet $(4 \mathrm{mmol} / \mathrm{L})$ inhibits TGF $\alpha$-induced DNA synthesis in rat hepatocytes. $* P<0.05$ with respect to cells treated with TGF $\alpha$ in the absence of AdoMet. 

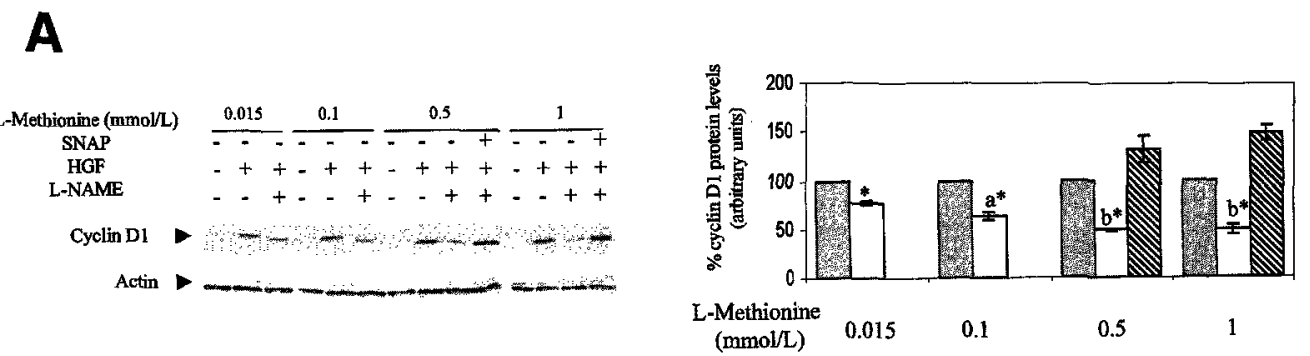

B
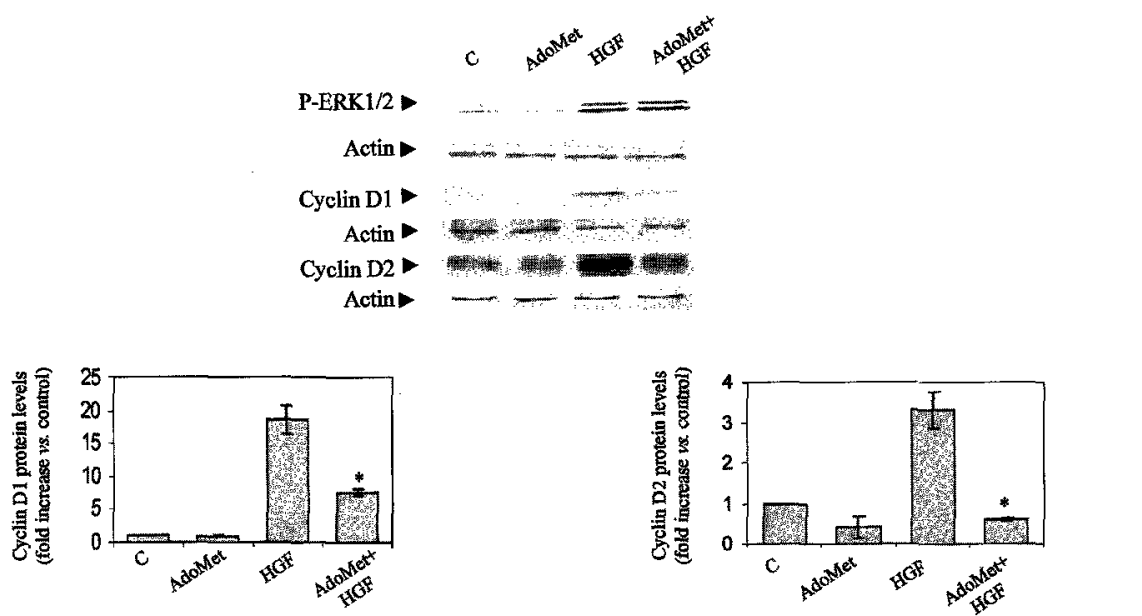

Figure 4. (A) Left panel: Induction of cyclin D1 expression (as determined by Western blot analysis) by HGF (25 ng/mL, 27-hour treatment) in rat hepatocytes is modulated by the concentration of L-methionine in culture medium when iNOS is inhibited by L-NAME (1 mmol/L). The addition of a NO donor (SNAP, $200 \mu \mathrm{mol} / \mathrm{L}$ ) reverses the inhibitory effect of L-methionine on HGF-induced cyclin D1 expression. Right panel: Quantitation

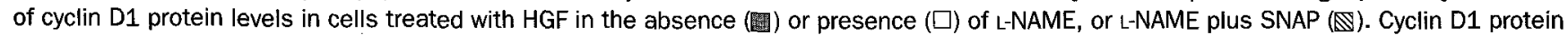
levels found in cells treated with HGF alone were given the arbitrary value of $100 \%$, all values were normalized to actin levels. $* P<0.05$ with respect to HGF alone in $0.015 \mathrm{mmol} / \mathrm{L} L$-methionine, a* indicates $P<0.05$ with respect to HGF plus L-NAME in $0.015 \mathrm{mmol} / \mathrm{L} \mathrm{L-methionine,}$ $\mathrm{b}^{*}$ indicates $P<0.05$ with respect to HGF plus L-NAME in $0.1 \mathrm{mmol} / \mathrm{L} L$-methionine. $(B)$ AdoMet treatment $(4 \mathrm{mmol} / \mathrm{L})$ does not interfere with the phosphorylation of ERK1/2 (P-ERK1/2) induced by HGF ( $25 \mathrm{ng} / \mathrm{mL}, 30$ minutes), but inhibits the induction of cyclin D1 and D2 expression elicited by HGF ( $25 \mathrm{ng} / \mathrm{mL}, 27$-hour treatment) in rat hepatocytes. Actin is shown as a loading control. Quantitation of cyclin D1 and D2 protein levels is shown, the levels of these proteins found in control cultures were given the arbitrary value of 1 , all values were normalized to actin levels. $* P<0.01$ with respect to HGF-treated cells. Experiments were performed 3 times in duplicate, representative Western blots are shown.

As shown in Figure $5 \mathrm{~A}$, in the presence of AdoMet, HGF-induced AP1 binding activity was attenuated. Members of the AP1 family include the c-Jun, JunB, JunD, c-Fos, FosB, and Fra1 proteins. ${ }^{29}$ In agreement with previous reports, ${ }^{24}$ supershift experiments showed that HGF-induced AP1 complex contained c-Jun, JunD, and Fral proteins (Figure $5 B$ ). The composition of this complex was altered in the presence of AdoMet, showing a drastic reduction in Fral contents (Figure $5 B$ ). The levels of c-Jun, JunB, JunD, c-Fos, and Fral proteins were examined by Western blotting in control and HGFtreated hepatocytes (10-hour treatment) in the presence or absence of AdoMet. As previously described, ${ }^{24}$ no major changes were detected in the expression of c-Jun, c-Fos, JunB, nor JunD after HGF treatment, whereas that of Fra1 was markedly induced (Figure $5 \mathrm{C}$ ). When HGF treatment was performed in the presence of AdoMet $(4 \mathrm{mmol} / \mathrm{L})$ the accumulation of Fra1 protein by HGF treatment was blunted (Figure $5 C$ ).

\section{Discussion}

Liver regeneration after $\mathrm{PH}$ is a complex and multistep process of which many aspects still remain unknown. A major area of research in this field is the identification of the signals that control the onset and termination of the hepatocyte proliferative response. Although HGF is a potent mitogen for cultured hepatocytes, injection of this growth factor in normal rats through the portal vein results in a poor mitogenic response. ${ }^{1,2}$ These observations suggest that hepatic parenchymal cells need to be primed to respond to proliferative signals. Different experimental approaches, including the use of knockout animal models, have shown that cytokines such as tumor necrosis factor $\alpha$ and interleukin 6 play a key role in the activation of growthregulatory pathways that could be part of this priming event. ${ }^{30-33}$ A combination of both cytokines has been shown to induce the expression of the iNOS gene, ${ }^{34}$ 
A
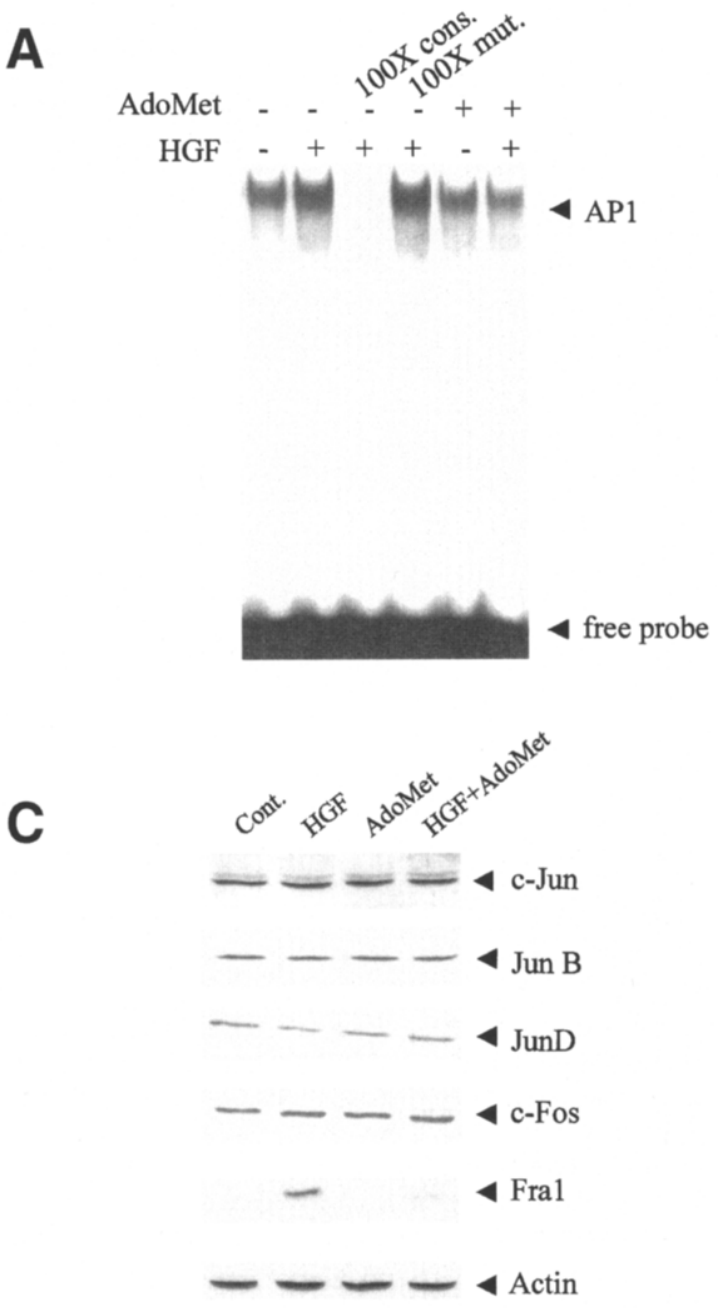

B
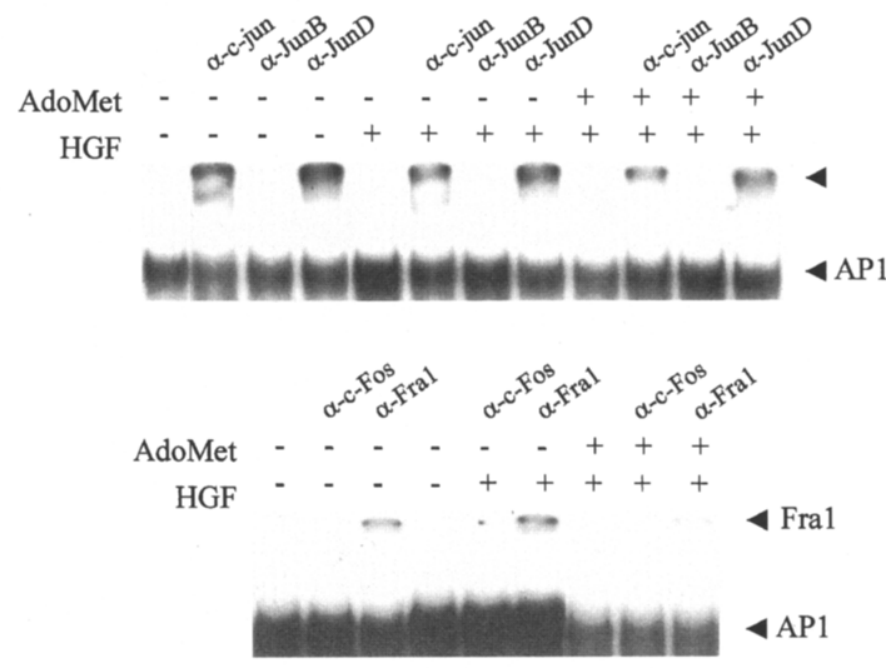

Figure 5. (A) Effect of AdoMet (4 mmol/L) on HGF (25 ng/mL, 24-hour treatment)-induced AP1 DNA binding activity in rat hepatocytes. Specificity of complexes was shown by the addition of 100-fold molar excess of cold AP1 consensus oligonucleotide (cons.) and 100-fold molar excess of mutant AP1 oligonucleotide (mut.). (B) Identification of the Fos and Jun proteins in the AP1-binding complexes. Nuclear extracts from control and treated hepatocytes (HGF $25 \mathrm{ng} / \mathrm{mL}, 24$ hours and AdoMet $4 \mathrm{mmol} / \mathrm{L}$ as indicated), were incubated with $4 \mu \mathrm{g}$ of specific antibodies against c-Jun, JunB, JunD, c-Fos, or Fra1 proteins followed by incubation with labeled AP1 probe and analyzed by electrophoretic mobility shift assay. Arrowhead indicates supershifted bands. $(C)$ Western blot analysis of Jun and Fos proteins in rat hepatocytes treated with HGF $(25 \mathrm{ng} / \mathrm{mL})$ for 10 hours in the absence or presence of AdoMet ( $4 \mathrm{mmol} / \mathrm{L})$. Actin is shown as a loading control. Experiments were performed 3 times in duplicate, representative autoradiograms and blots are shown. which also occurs in the liver after $\mathrm{PH}$ before the onset of DNA synthesis. ${ }^{35}$ NO production seems to be an important response of the remaining liver parenchyma because inhibition of iNOS with L-NAME decreases hepatocyte proliferation and iNOS knockout mice display impaired liver regeneration after PH, ${ }^{5,6}$ In iNOS knockout mice, hepatocytes undergo necrosis and apoptosis after $\mathrm{PH}$, indicating that the production of NO was essential to protect hepatocytes from death after liver resection. ${ }^{6}$ Our present observations suggest that, in addition to this protective role, NO could also play an important function in the sensitization of the hepatocyte to the mitogenic action of growth factors such as HGF and TGF $\alpha$. In agreement with previous reports we observed that iNOS expression was induced in cultured hepatocytes isolated by the collagenase perfusion method. ${ }^{19,20}$ The proliferative response of these cells to HGF was dependent on iNOS activity because its inhibition with L-NAME resulted in impaired DNA synthesis. Furthermore, the inhibitory effect of L-NAME was overcome by the NO donor SNAP. The growth-promot- ing effects of NO are not unique to the liver, and have been observed in other cellular backgrounds such as the endothelial cell. ${ }^{36}$

The hepatoprotective effect of NO after $\mathrm{PH}$ has been attributed in part to the nitrosylation and consequent inactivation of caspase 3 in Cys-163, a key residue required for full proteolytic activity and for the development of apoptosis. ${ }^{6,37,38} \mathrm{We}$ have observed that the inhibitory effect of L-NAME on HGF-induced hepatocyte proliferation was dependent on the concentration of Lmethionine present in the incubation media, whereas the nonmetabolizable analogue $\mathrm{D}$-methionine had no effect. As mentioned previously, L-methionine metabolism in the liver starts with the formation of AdoMet, a reaction catalyzed by MAT I/III, which is a well-characterized target for NO in the hepatocyte. We have previously shown that MAT I/III is inhibited by NO in vitro and in vivo through the nitrosylation of Cys-121, a residue unique to the hepatocyte-specific MAT protein (MAT I/III), which is absent in the NO-resistant MAT II isoenzyme, expressed in all other cell types. ${ }^{9-12}$ Inhibi- 
tion of MAT I/III by NO leads to the reduction of intracellular AdoMet levels. ${ }^{12}$ Consequently, when MAT I/III was protected from NO-mediated inactivation by L-NAME we observed higher MAT activity and AdoMet contents, and the hepatocyte was rendered refractory to HGF-induced DNA synthesis. The observation that this effect was dependent on the concentration of methionine in the culture medium further suggested that it was mediated by AdoMet. Accordingly, when L-methionine was substituted by AdoMet we also observed a dosedependent inhibition in the proliferative response to HGF. This effect was observed at all time points tested, for up to 72 hours of treatment, suggesting that DNA synthesis was not merely delayed but was indeed inhibited. These observations were also extended to TGF $\alpha$, another growth factor for hepatocytes that may be relevant in the regenerative process of the liver. ${ }^{1}$ To identify the level at which AdoMet inhibits the mitogenic activity of HGF, growth-factor signaling was tested in cultured hepatocytes. We have previously observed that HGF-stimulated $\mathrm{p} 190^{M E T}$ tyrosine kinase activity is not inhibited by AdoMet treatment. ${ }^{16}$ Similarly, now we report that the subsequent activation of ERK1/2 by HGF is similar in the presence or absence of AdoMet. This suggests that AdoMet would act downstream of ERK1/2 activation, through the regulation of molecular events that could include the modulation of ERK1/2 oligomerization and nuclear translocation, and the regulation of phosphatase activity or transcription factor phosphorylation, which lies between ERK1/2 activation and induction of gene expression. ${ }^{39}$ Downstream of ERK1/2 activation the up-regulation of type $\mathrm{D}$ cyclins is believed to play an important role during the G1 phase in many cell types, including hepatocytes, providing a link between mitogen signaling and the cell cycle machinery. ${ }^{2,40} \mathrm{Cy}$ clin D1 is induced in rodent liver after $\mathrm{PH}$ and in regenerating human liver, ${ }^{41,42}$ moreover, its overexpression in primary rat hepatocytes causes DNA replication in the absence of growth factors and leads to hepatocellular carcinoma in transgenic mice. ${ }^{43,44}$ Our present results showing that AdoMet treatment inhibited HGFinduced cyclin D1 and D2 expression suggest that the intracellular levels of this metabolite may indeed modulate a key response in the mitogenic signaling of HGF. Similar results were obtained when HGF treatment was performed in the presence of L-NAME and increasing concentrations of L-methionine in the culture medium, supporting the specificity of the effect of AdoMet and the physiological nature of this response. Inhibition of cyclin D1 expression by AdoMet also may be relevant regarding the antineoplastic properties of AdoMet administration in chemically induced rat hepatocarcinoma. $7,14,17$

Activation of transcription factors such as AP1 and nuclear factor- $\mathrm{kB}$ (NF- $\mathrm{kB}$ ) occurs after $\mathrm{PH}$ and is thought to modulate the expression of genes involved in liver regeneration., ${ }^{2,28}$ It is known that HGF promotes the activation of AP1 and NF-KB in cultured hepatocytes. ${ }^{24,27}$ We have recently shown that AdoMet modulates NF- $\mathrm{KB}$ activation in isolated rat hepatocytes through the up-regulation of inhibitor kappa $B$ alpha $(\mathrm{I} \kappa \mathrm{B} \boldsymbol{\alpha})$ levels..$^{45}$ Now we have tested the effect of AdoMet on HGF-induced AP1 activation. We observed that in the presence of AdoMet, the DNA binding activity of AP1 stimulated by HGF was attenuated. This effect may be caused in part by the marked inhibition of HGFinduced Fral expression by AdoMet. In addition, the absence of Fral would favor the formation of the less active c-Jun/JunD heterodimers. ${ }^{29}$ These observations could be of significance regarding the inhibition of cyclin D1 expression by AdoMet because this gene can be induced through the activation of NF- $\mathrm{KB}$ and AP1 transcription factors. ${ }^{40}$ In summary (Figure 6), our observations suggest that fluctuations in liver AdoMet contents after $\mathrm{PH}$, caused by the NO-mediated inhibition of MAT I/III, may represent a novel mechanism that regulates the onset of the hepatocyte proliferative response

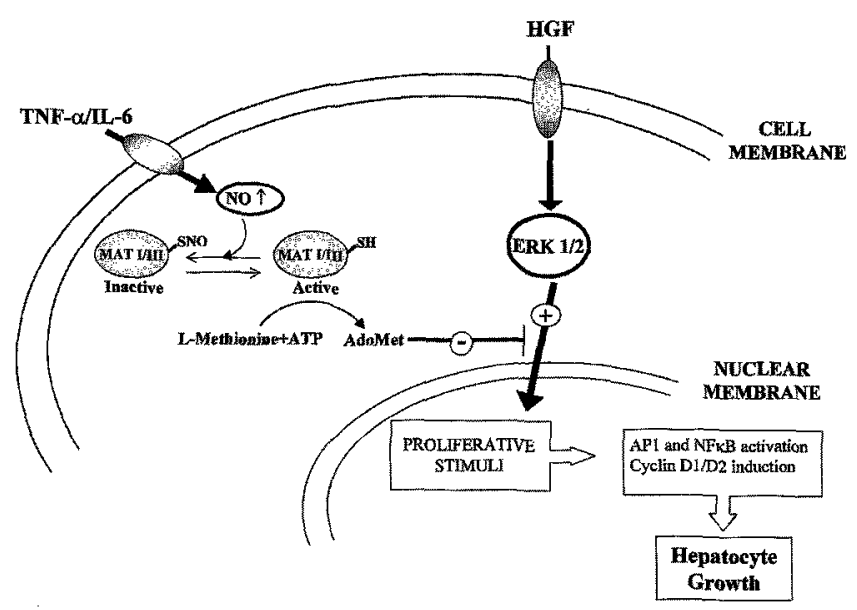

Figure 6. Activation of iNOS and NO production sensitize rat hepatocytes to the mitogenic stimulus of mitogens such as HGF and TGF $\alpha$ through the modulation of intracellular AdoMet levels. Increased NO production in the hepatocyte, in response to cytokines after $\mathrm{PH}$ or collagenase perfusion, leads to the specific inactivation of MAT I/III through S-nitrosylation of cysteine 121, and, consequently, to the reduction of intracellular AdoMet levels. When NO generation is prevented by iNOS inhibitors, and thus MAT I/III activity is preserved, the proliferative response to HGF is dose-dependently inhibited by Lmethionine present in the culture medium. Exogenous addition of AdoMet mimics the inhibitory effect of L-methionine on HGF-induced hepatocyte proliferation, which can be mediated in part through reduced activation of AP1 and NF-kB transcription factors and type D cyclin expression. 
during liver regeneration. Nevertheless, the significance of these findings still needs to be tested in an in vivo setring.

\section{References}

1. Michalopoulos GK, DeFrances MC. Liver regeneration. Science 1997;276:60-66.

2. Fausto N. Liver regeneration. J Hepatol 2000;32(Suppl 1):1931.

3. Higgins GM, Anderson RM. Experimental pathology of the liver. I. Restoration of the liver of the white rat following partial surgical removal. Arch Pathol 1931;12:186-202.

4. Overturf K, al-Dhalimy M, Ou CN, Finegold M, Grompe M. Serial transplantation reveals the stem-cell-like regenerative potential of adult mouse hepatocytes. Am J Pathol 1997;151:1273-1280.

5. Hortelano S, Dewez B, Genaro AM, Diaz-Guerra MJM, Bosca L. Nitric oxide is released in regenerating liver after partial hepatectomy. Hepatology 1995;21:776-786.

6. Rai RM, Lee FYJ, Rosen A, Yang SQ, Lin HZ, Koteish A, Liew FY, Zaragoza $C$, Lowenstein $C$, Diehl AM. Impaired liver regeneration in inducible nitric oxide synthase-deficient mice. Proc Natl Acad Sci U S A 1998;95:13829-13834.

7. Mato JM, Alvarez L, Ortiz P, Pajares MA. S-Adenosylmethionine synthesis: molecular mechanisms and clinical implications. Pharmacol Ther 1997;73:265-280.

8. Kotb M, Mudd SH, Mato JM, Geller AM, Kredich NM, Chou JY, Cantoni GL. Consensus nomenclature for the mammalian methionine adenosyltransferase genes and gene products. Trends Genet 1997;13:51-52.

9. Avila MA, Mingorance J, Martinez-Chantar ML, Casado M, MartínSanz P, Bosca L, Mato JM. Regulation of rat liver S-adenosylmethionine synthetase during septic shock: role of nitric oxide. Hepatology 1997;25:391-396.

10. Avila MA, Carretero MV, Rodriguez EN, Mato JM. Regulation by hypoxia of methionine adenosyltransferase activity and gene expression in rat hepatocytes. Gastroenterology 1998;114:364371.

11. Ruiz F, Corrales FJ, Miqueo C, Mato JM. Nitric oxide inactivates rat hepatic methionine adenosyltransferase in vivo by S-nitrosylation. Hepatology 1998;28:1051-1057.

12. Perez-Mato I, Castro C, Ruiz F, Corrales FJ, Mato JM. Methionine adenosyltransferase $\mathrm{S}$-nitrosylation is regulated by the basic and acidic amino acids surrounding the target thiol. I Biol Chem 1999;274:17075-17080.

13. Huang ZZ, Mao Z, Cai J, Lu SC. Changes in methionine adenosyltransferase during liver regeneration in the rat. Am J Physiol 1998;275:G14-G21.

14. Pascale RM, Simile MM, Satta G, Seddaiu MA, Daino L, Pinna G, Vinci MA, Gaspa L, Feo F. Comparative effects of L-methionine, $S$-adenosyl-L-methionine and $5^{\prime}$-methylthioadenosine on the growth of preneoplastic lesions and DNA methylation in rat liver during the early stages of hepatocarcinogenesis. Anticancer Res 1991;11:1617-1624.

15. Shivapurkar N, Hoover KL, Poirier LA. Effect of methionine and choline on liver tumor promotion by phenobarbital and DDT in diethylnitrosamine-initiated rats. Carcinogenesis 1986;8:615617.

16. Latasa MU, Boukaba A, Garcia-Trevijano ER, Torres L, Rodríguez JL, Caballería J, Lu SC, López-Rodas G, Franco L, Mato JM, Avila MA. Hepatocyte growth factor induces MAT2A expression and histone acetylation in rat hepatocytes: role in liver regeneration. FASEB $J$ 2001;15:1248-1250.

17. Cai J, Mao Z, Hwang J, Lu SC. Differential expression of methionine adenosyltransferase genes influences the rate of growth of human hepatocellular carcinoma cells. Cancer Res 1998;58: 1444-1450.
18. Lu SC, Alvarez L, Huang ZZ, Chen L, An W, Corrales FJ, Avila MA, Kanel G, Mato JM. Methionine adenosyltransferase $1 \mathrm{~A}$ knockout mice are predisposed to liver injury and exhibit increased expression of genes involved in proliferation. Proc Natl Acad Sci U S A 2001;98:5560-5565.

19. Wang $H$, Gao X, Fukumoto S, Tademoto S, Sato K, Hirai $K$. Post-isolation inducible nitric oxide synthase gene expression due to collagenase buffer perfusion and characterization of the gene regulation in primary cultured murine hepatocytes. $J$ Biochem 1998;124:892-899.

20. López-García MP. Endogenous nitric oxide is responsible for the loss of P450 in cultured rat hepatocytes. FEBS Lett 1998;438: 145-149.

21. Leffert HL, Koch KS, Moran T, Williams M. Liver cells. Methods Enzymol 1979;58:536-544.

22. Garcia-Trevijano ER, Latasa MU, Carretero MV, Berasain C, Mato $J M$, Avila MA. S-adenosylmethionine regulates MAT1A and MAT2A gene expression in cultured rat hepatocytes: a new role for S-adenosylmethionine in the maintenance of the differentiated status of the liver. FASEB J 2000;14:2511-2518.

23. Cabrero C, Martin-Duce A, Ortiz P, Mato JM. Specific loss of the high-molecular weight form of S-adenosyl-L-methionine synthetase in human liver cirrhosis. Hepatology 1988;8:15301534.

24. Rahmani M, Nadori F, Durand-Schneider AM, Lardeux B, Bernuau D. Hepatocyte growth factor activates the AP-1 complex: a comparison between normal and transformed rat hepatocytes. J Hepatol 1999;30:916-925.

25. Loyer P, Cariou S, Glaise D, Bilodeau M, Baffet G, GuguenGuillouzo $C$. Growth factor dependence of progression through $\mathrm{G} 1$ and $S$ phases of adult rat hepatocytes in vitro. Evidence of a mitogen restriction point in mid-late G1. I Biol Chem 1996;271: 11484-11492.

26. Moriuchi A, Hirono S, Ido A, Ochiai T, Nakama T, Uto H, Hori T, Hayashi $K$, Tsubouchi $H$. Additive and inhibitory effects of simultaneous treatment with growth factors on DNA synthesis through MAPK pathway and G1 cyclins in rat hepatocytes. Biochem Biophys Res Commun 2001;280:368-373.

27. Rahmani M, Péron P, Weitzman J, Bakiri L, Lardeux B, Bernuau D. Functional cooperation between JunD and NF-kB in rat hepatocytes. Oncogene 2001;20:5131-5142.

28. Taub R. Transcriptional control of liver regeneration. FASEB J 1996;10:413-427.

29. Mechta-Grigoriou F, Gerald D, Yaniv M. The mammalian Jun proteins: redundancy and specificity. Oncogene 2001;20:23782389.

30. Akerman P, Cote P, Yang SQ, McClain C, Nelson S, Bagby GJ, Diehl AM. Antibodies to tumor necrosis factor-alpha inhibit liver regeneration after partial hepatectomy. Am J Physiol 1992;263: G579-G585.

31. Yamada Y, Kirillova I, Peschon JJ, Fausto N. Initiation of liver growth by tumor necrosis factor: deficient liver regeneration in mice lacking type I tumor necrosis factor receptor. Proc Natl Acad Sci U S A 1997;94:1441-1446.

32. Cressman DE, Greenbaum LE, DeAngelis RA, Ciliberto G, Furth EE, Poli V, Taub R. Liver failure and defective hepatocyte regeneration in interleukin-6-deficient mice. Science 1996;274:13691383.

33. Webber EM, Bruix J, Pierce RH, Fausto N. Tumor necrosis factor primes hepatocytes for DNA replication in the rat. Hepatology 1998;28:1226-1234.

34. Li J, Billiar T. Nitric oxide. IV. Determinants of nitric oxide protection and toxicity in liver. Am J Physiol 1999;276:G1069-G1073.

35. Obolenskaya $M$, Schulze-Specking A, Plaumann B, Frenzer $K$, Freudenberg N, Decker K. Nitric oxide production by cells isolated from regenerating rat liver. Biochem Biophys Res Commun 1994; 204:1305-1311. 
36. Parenti A, Morbidelli L, Cui XL, Douglas JG, Hood JD, Granger HJ, Ledda F, Ziche M. Nitric oxide is an upstream signal of vascular endothelial growth factor-induced extracellular signal-regulated kinase $1 / 2$ activation in postcapillary endothelium. $J$ Biol Chem 1998;273:4220-4226

37. Li J, Billiar TR, Talanian RV, Kim YM. Nitric oxide reversibly inhibits seven members of the caspase family via S-nitrosylation. Biochem Biophys Res Commun 1997;240:419-424.

38. Mannik JB, Hausladen A, Liu L, Hess DT, Zeng M, Miao QX, Kane LS, Gow AJ, Stamler JS. Fas-induced caspase denitrosylation. Science 1999;284:651-654.

39. Brunet A, Roux D, Lenormand P, Dowd S, Keyse S, Poyssegur J. Nuclear translocation of $\mathrm{p} 42 / \mathrm{p} 44$ mitogen-activated protein kinase is required for growth factor-induced gene expression and cell cycle entry. EMBO J 1999;18:664-674.

40. Ekholm SV, Reed SI. Regulation of $\mathrm{G}_{1}$ cyclin-dependent kinases in the mammalian cell cycle. Curr Opin Cell Biol 2000;12:676684.

41. Kato $A$, Ota S, Bamba H, Wong RM, Ohmura E, Imai $Y$, Matsuzaki F. Regulation of cyclin D-dependent kinase activity in rat liver regeneration. Biochem Biophys Res Commun 1998;245:70-74.

42. Albrecht JH, Hu MY, Cerra FB. Distinct patterns of cyclin D1 regulation in models of liver regeneration and human liver. Biochem Biophys Res Commun 1995;209:648-655.

43. Albretch JH, Hansen LK. Cyclin D1 promotes mitogen-independent cell cycle progression in hepatocytes. Cell Growth Differ 1999;10:397-404.
44. Deane NG, Parker MA, Aramandla R, DiehI L, Lee WJ, Washington MK, Nanney LB, Shyr Y, Beauchamp RD. Hepatocellular carcinoma results from chronic cyclin D1 overexpression in transgenic mice. Cancer Res 2001;61:5389-5395.

45. Majano PL, García-Monzón C, García-Trevijano ER, Corrales FJ, Cámara J, Ortiz P, Mato JM, Avila MA, Moreno-Otero R. S-adenosylmethionine modulates inducible nitric oxide synthase gene expression in rat liver and isolated hepatocytes. J Hepatol 2001; 35:692-699.

Received September 24, 2001. Accepted January 3, 2002.

Address requests for reprints to: Professor José M. Mato, Departamento de Medicina Interna, Edificio Los Castaños, Facultad de Medicina, Universidad de Navarra, 31008 Pamplona, Spain. e-mail: jmmato@unav.es; fax: (34) 948-425677.

J.M.M. and M.A.A. share senior authorship.

Supported by grants $99 / 0038$ from Plan Nacional de I+D, Ministerio de Educación y Ciencia; and Knoll (to J.M.M.); grant ROI AA-12677 from the National Institute on Alcohol Abuse and Alcoholism (to J.M.M. and M.A.A.); grant FIS from Ministerio de Sanidad y Consumo (to M.A.A.); grants $681 / 2000$ and 349/2001 from Gobierno de Navarra (to J.M.M. and M.A.A., respectively); and a grant from Fundación Renal Iñigo Alvarez de Toledo, Spain (to J.M.M.).

The authors acknowledge the technical support of Estefanía Fernández. 